\title{
The New Life of the Good Souls in Josephus: Resurrection or Reincarnation?
}

\author{
Sami Yli-Karjanmaa \\ University of Helsinki, Helsinki, Finland \\ sami.yli-karjanmaa@helsinki.fi
}

\begin{abstract}
This study examines four Josephan passages discussing souls entering a new body or life. It argues that research on this issue can be advanced from the conclusion by several scholars that despite the language of reincarnation it is really the belief in resurrection that underlies Josephus's accounts. The key findings include: Josephus does not directly characterize the new life as a reward, and the fact that its recipients are good souls does not contradict reincarnation. The descriptions of the new body in B.J. are in all respects easier to reconcile with reincarnation than resurrection. The expression $\dot{\varkappa} \chi \pi \varepsilon \rho \iota p \circ \pi \hat{\varsigma} \varsigma$ ( $\alpha i \omega^{\prime} \nu \omega \nu$ ) is best understood as referring to (cyclical) recurrence. The Josephan version of re-embodiment that emerges has many exact similarities with accounts of reincarnation but only a few general ones with resurrection. The thesis that Josephus's real referent is resurrection is implausible.
\end{abstract}

\section{Keywords}

Josephus - soul - body - afterlife - resurrection - reincarnation - Plato

* Acknowledgements. This paper is partly based on two papers I have given. The first one was in the workshop "Ancient Jewish Cosmologies" organized by the Academy of Finland Centre of Excellence in "Changes in Sacred Texts and Traditions" (CSTT) in Jerusalem in June 2015, and the second in the New Testament Research Seminar of Durham University in January 2016. I thank the participants, Elisa Uusimäki and John Barclay in particular, for very useful feedback. During the writing of this paper I was employed by the CSTT, based at the Department of Biblical Studies of the Faculty of Theology, University of Helsinki.

(C) SAMI YLI-KARJANMAA, 2017 | DOI 10.1163/15700631-12340154

This is an open access article distributed under the terms of the prevailing CC-BY-NC license at the time of publication. 


\section{Introduction}

The descriptions of afterlife beliefs in the works of Flavius Josephus have given rise to several kinds of interpretations among scholars. Many of these descriptions either concern views Josephus attributes to the three Jewish schools of "philosophy" (the Essenes, the Pharisees and the Sadducees) or are contained in the Jewish War in speeches by different parties, including the historian himself. ${ }^{1}$ The questions of what exactly the various texts imply will happen to the soul after death and what terminology scholars should use remain contested.

This article focuses on a group of four passages in which Josephus speaks of the soul passing post mortem to "a different body" (B.J. 2.163), experiencing a "revival" (A.J. 18.14), returning to "a holy body" (B.J. 3.374) and "being born again" and "receiving a better life" (C.Ap. 2.218). For the sake of convenience, I use the generic term "new life" when referring to the phenomenon described in these passages. ${ }^{2}$ The main interpretations which scholars have put forward for these passages are two different doctrines of re-embodiment, the resurrection of the body and the reincarnation of the soul (i.e., transmigration or metempsychosis). ${ }^{3}$ In addition to more or less clearly choosing one or the other

1 For a list of thirty afterlife passages, see Joseph Sievers, "Josephus and the Afterlife," in Understanding Josephus: Seven Perspectives, ed. Steve Mason (Sheffield: Sheffield Academic Press, 1998), 23-24, and for a synopsis of thirteen texts, Casey D. Elledge, Life after Death in Early Judaism: The Evidence of Josephus, wUNT 2.208 (Tübingen: Mohr Siebeck, 2006), 168-75. My use of the terms Jews and Jewish (which I consider to be ethnic and cultural, not only religious terms) and not Judean(s) in this article is not meant to deny the varying degrees of

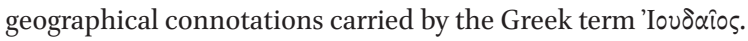

2 There is no reason to think the passages do not discuss the same phenomenon; so also Steve Mason, Flavius Josephus on the Pharisees: A Composition-Critical Study, StPB 39 (Leiden: Brill, 1991), 299.

3 For the definitions of these terms see below. Resurrection has been preferred, e.g., by Jonathan Klawans, Josephus and the Theologies of Ancient Judaism (Oxford: Oxford University Press, 2012), 111, 119; Émile Puech, La croyance des Esséniens en la vie future: immortalité, résurrection, vie éternelle? Histoire d'une croyance dans le judaïsme ancien, 2 vols., Etudes bibliques, nouvelle serie 22 (Paris: Gabalda, 1993), 2:717; James D. Tabor, “'Returning to the Divinity': Josephus's Portrayal of the Disappearances of Enoch, Elijah, and Moses," JBL 108 (1989): 22538, esp. 232; and Louis H. Feldman, Josephus and Modern Scholarship (1937-1980) (Berlin: de Gruyter, 1984), 10. The scholars who have opted for reincarnation include Lester L. Grabbe, "Eschatology in Philo and Josephus," in Death, Life-After-Death, Resurrection and The Worldto-Come in the Judaisms of Antiquity, ed. Alan Avery-Peck and Jacob Neusner, HO 1.49 (Leiden: Brill, 2000), 176-77; A. E. Harvey, Jesus and the Constraints of History: The Bampton Lectures, 
option, according to a third main view it is the case that while Josephus uses expressions that in themselves refer to reincarnation, a belief in resurrection nevertheless underlies his accounts. ${ }^{4}$ Finally, some scholars agree with the previous group that we should not take Josephus's reincarnational language at face value. They do not, however, maintain that its real referent is resurrection but think instead that we cannot say much of the actual beliefs behind the accounts. ${ }^{5}$

Two observations can be made of these four views. ${ }^{6}$ First, the three last ones seem to imply that-regardless of the historical reality-Josephus himself wanted his audience to understand his references to a new life as endorsements of reincarnation. But also three views (the first and the two last ones) imply that he really refers to something else. From this state of affairs stems the central question of this article: Is it warranted to regard Josephus's descriptions of reincarnation as anomalous and to take the new life passages as veiled references to resurrection and/or based on belief in it? Most versions of the view that such warrant exists rest on some general thesis that can be questionede.g., that Josephus's apologetic motivation makes him unreliable, ${ }^{7}$ or that

1980 (London: Duckworth, 1982), 150 and Henry St. J. Thackeray, note to his Loeb translation at B.J. 2.163.

4 E.g., Francis T. Glasson, Greek Influence in Jewish Eschatology (London: SPCK, 1961), 2830; N. T. Wright, The Resurrection of the Son of God (London: SPCK, 2003), 177-78; Casey D. Elledge, "Resurrection and Immortality in Hellenistic Judaism: Navigating the Conceptual Boundaries," in Christian Origins and Hellenistic Judaism: Social and Literary Contexts for the New Testament, ed. Stanley E. Porter and Andrew W. Pitts, TENTs 9 (Leiden: Brill, 2013), 112-13. I would classify in this group also Steve Mason (see, e.g., Pharisees, 169 n. 207), but see n. 13 below.

5 Alan Segal, Life after Death: A History of the Afterlife in the Religions of the West (New York: Doubleday, 2004), 381; E. P. Sanders, Judaism: Practice and Belief 63 BCE-66 CE (London: SCM Press, 1994), 301-3.

6 It should be noted that although this division into four reasonably reflects the status quaestionis, it cannot do full justice to the nuances of individual scholars' views. E.g., Klawans shows some understanding for regarding Josephus "as attributing to the Pharisees something between reincarnation and resurrection" (Josephus, 108)—although it remains unclear what exactly he means by referring in this context to the ostensible differences between the concepts of reincarnation, metempsychosis and transmigration. I regard these as synonyms; see John Bowker, ed., Oxford Concise Dictionary of World Religions (Oxford: Oxford University Press, 2000), s.v. "rebirth."

7 Criticized in general terms by Mason, Pharisees, 15 . This view has been represented recently by, e.g., Elledge (see note 14 below). 
reincarnation was, a priori, "étrangère au judaïsme"8_or on inaccurate premises. $^{9}$

Before proceeding to the examination of the passages two methodological preliminaries need to be discussed.

First, in the interest of conceptual clarity resurrection and reincarnation should be defined. ${ }^{10}$ Indeed, otherwise it becomes difficult to assess the passages in relation to the two doctrines, which do differ with regard to the manner, recurrence and context of the new incarnation. Resurrection can be defined, as Jonathan Klawans does, as an event whereby “an individual's life is restored back to a living body,"11 but this should be further specified by adding that this is a one-time return which is to take place in a collective eschatological fulfillment. The body is believed to be either the one the person had during her/his life or of some other kind; no ordinary birth is involved. Reincarnation, on the other hand, is a repeated process which involves several ordinary births. It precedes the eschaton of an individual soul, i.e., its salvation out of the corporeal existence. Unlike in resurrection, the new body is "destined to die, too." 12 These definitions by no means imply that Josephus's accounts must neatly fit one category or the other. Their purpose is simply to enhance understandability. ${ }^{13}$

8 Puech, Croyance, 2:717. This view seems incorrect. The first-century CE Jewish exegete Philo of Alexandria has been suspected of endorsing reincarnation in printed literature since the sixteenth century, a view whose accuracy I have argued for in Reincarnation in Philo of Alexandria, SPhiloM 7 (Atlanta: Society of Biblical Literature, 2015).

E.g., as discussed below, the points (a) to (d) that act as a summary of Mason's inquiry into the "anomaly" of the new body being a reward are not entirely accurate and do not support his thesis of the Josephan accounts of reincarnation being "peculiar" and rather resembling resurrection (Pharisees, 169). Likewise, two of the four points he calls "fundamental to every other theory of reincarnation" (ibid., 166.) are problematic. Point (2)"life in the body results from a fall" - is perhaps neither relevant, since Josephus nowhere discusses the original cause of the soul's embodiment, nor entirely correct. For instance, in Plato's Timaeus the souls' first incarnation is not related to a fall-only the subsequent ones are. For the other points, see below, nn. 34, 48.

Here I agree about the importance of clearly defining these concepts with Klawans, Josephus, 108; Wright, Resurrection, 178.

11 Klawans, Josephus, 93. Instead of "life" we could also say, "soul."

12 Ibid., 107.

13 Scholars sometimes use language that conflates the two concepts in an unhelpful way. Thus Steve Mason says that resurrection and reincarnation do not need to be mutually exclusive and that Josephus apparently considered the former to be "the Jewish mode" of the latter (Pharisees, 169 n. 207). According to John J. Collins, Josephus expresses "belief in 
Second, the present study aims to separate a primary, "exegetical" phase of investigation from a secondary, historical one, as soundly suggested by Steve Mason. ${ }^{14}$ That is, we need to first comprehend as fully as possible what Josephus wants to say and then try to assess if he is being accurate and truthful. This article focuses on the first phase. Comparative material is evoked for the purpose of understanding what Josephus intends to convey, not in order to verify the Pharisees' (or his own) actual beliefs.

The boundary between the two phases is not always easy to discern. E.g., Mason has stated, "[i]t is a historical question, beyond the scope of this study, whether Josephus misrepresented the Jewish doctrine of resurrection by appropriating Greek terminology [of reincarnation] for it."15 One may ask if Mason's claim itself that Josephus used reincarnation terminology for resurrection is not already his affirmative answer to that historical question. His argument also raises the question of how Josephus's own audience(s) would have seen his accounts. ${ }^{16}$ Would they have made the same conclusions as Mason, namely that despite "the common language of reincarnation, those views still

both resurrection (in the form of metempsychosis) and the immortality of the soul"; see "Eschatology," ed. Collins and Daniel C. Harlow, The Eerdmans Dictionary of Early Judaism (Grand Rapids: Eerdmans, 2010), 596. In a similar vein Günter Stemberger, Pharisäer Sadduzäer Essener: Fragen-Fakten-Hintergründe (Stuttgart: Katholisches Bibelwerk, 2013), 63, speaks of an "Auferstehungsleib" in connection with the Pharisaic belief (as portrayed by Josephus) in "Seelenwanderung." In these cases it is difficult to know what is implied with regard to the manner, recurrence and context of the new embodiment.

14 He is here following Neusner and Rivkin. For an enlightening discussion with references, see Mason, Pharisees, 12-16. In a markedly different approach, Elledge takes as his starting point "regard[ing] Josephus as an apologetical translator, who has transformed the original content of Jewish beliefs regarding the future life into a Hellenistic philosophical synthesis for his own rhetorical purposes" (Life and Death, 3 and passim). Klawans commends Elledge's approach but implicitly acknowledges the importance of the exegetical phase when he says that the answer to the question of "whether behind [Josephus's 'apologetic'] translation we can discern anything of historical value" depends on "our own understandings — and translations — of Josephus's curious descriptions of Pharisaic beliefs" (Josephus, 107).

15 Pharisees, 169.

16 Josephus mentions Vespasian and Titus as the primary audience of $B . J$., but he also mentions (Palestinian) Jews with Greek education (C. Ap. 1.51; cf. Vita 359). For Josephus's audience(s), see Steve Mason, A History of the Jewish War: AD 66-74 (Cambridge: Cambridge University Press, 2016), 83-88. 
seem peculiar in the Greco-Roman context" and that what Josephus is talking about rather "bears many similarities to what we should call resurrection"? In other words, do these conclusions belong to the exegetical phase or are they part of the reconstruction by the modern historian? By discussing them without reservations, Mason implies the former. He does not, however, make it explicit whether he thinks Josephus intended his descriptions of reincarnation as peculiar to the effect that they would turn the minds of at least some in the audience to resurrection instead - just like has happened to many a modern scholar.

In order not to belittle the possibility that there are hints at resurrection in Josephus's accounts, I have chosen to look at them from the viewpoint of such a contemporary audience which is knowledgeable of both Greek and Jewish afterlife beliefs.

The passages dealing with a "new life" must be read in their contexts which can be briefly described as follows. The notion is twice presented as a Pharisaic belief: B.J. 2.163 and A.J. 18.14 are part of Josephus's descriptions of the Jewish "philosophical" schools (B.J. 2.119-166; A.J. 18.11-23). The two remaining occurrences are to be attributed to Josephus himself: $B . J .3 \cdot 374$ belongs to his "philosophical" speech to his troops at Jotapata against collective suicide (3.362-382), and C.Ap. 2.218 is part of the summary of punishments for transgressing and rewards for observing and defending the Mosaic legislation (2.215-218). The following table presents the passages grouped according to their commonalities. As can be seen, in both columns (Pharisees/Josephus) one passage speaks of a new body, the other one of a new life.

This study proceeds in four steps in which I address the following questions that I have deemed to shed the most light on how the passages should be understood. First, I deal with the issue of whether the new life should be seen specifically as a reward. Second, I examine the characterizations of the body in B.J. 2 and 3 to determine if they should be regarded as references to a resurrection body. Third, I analyze the provenance of the terminology Josephus uses of the new and better life in the A.J. and C. Ap. passages. Finally, I try to answer the question of whether the process described in B.J. 3 and C. Ap. is a recurring one. 
New B.J. 2.163 (tr. Mason): "Al-

Body though every soul is imperishable, only that of the good passes over to a different body, whereas those of the vile are punished by eternal retribution."18
B.J. 3.372, 374-375 (tr. Thackeray): "All of us, it is true, have mortal bodies, composed of perishable matter, but the soul lives for ever, immortal: it is a portion of the Deity housed in our bodies.... [the souls of those] who depart this life in accordance with the law of nature... remaining spotless and obedient, are allotted the most holy place in heaven, whence, in the revolution of the ages, they return to find in chaste bodies a new habitation. [But] those who have laid mad hands upon themselves, the darker regions of the nether world receive their souls, and God, their father, visits upon their posterity the outrageous acts of the parents." 19

I do not in all respects agree with the English translations in the table and will present my amendments at the end of this article. Unless otherwise indicated, all translations of all authors are from the Loeb Classical Library. For B.J. 2 I use Steve Mason, Flavius Josephus: Translation and Commentary, Vol. 1 B: Judean War 2 (Leiden: Brill, 2008) and for C. Ap. John Barclay, Flavius Josephus: Translation and Commentary, Vol. 10: Against Apion (Leiden: Brill, 2007).

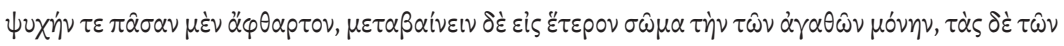

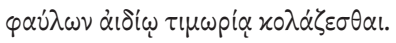

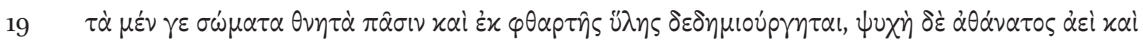

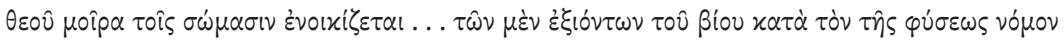

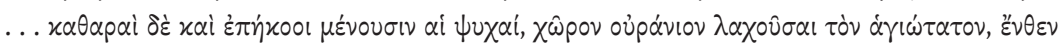

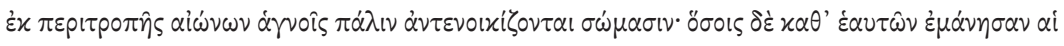

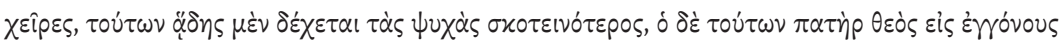

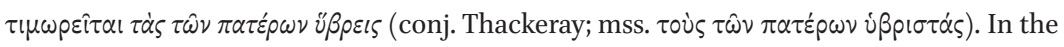
Slavonic version of $B . J$. the good soul "passes from its first to a purer body" in 2.163, whereas 3.374 contains no adjectival attribute: "Their pure and spotless souls remain in a holy and celestial place and await [the moment] thence again to settle in their bodies when the ages return" (H. Leeming, K. Leeming and L. Osinkina, Josephus' Jewish War and Its Slavonic Version [Leiden: Brill, 2003]). The Old Latin translation agrees with the Greek: B.J. 2.163 has "in alia corpora," 3.374, "casta corpora." 
The Pharisees

Josephus himself

New A.J. 18.14 (tr. Feldman): "They

Life believe that souls have power to survive death and that there are rewards and punishments under the earth for those who have led lives of virtue or vice; eternal imprisonment is the lot of evil souls, while the good souls receive an easy passage to a new life." 20
C. Ap. 2.218 (tr. Barclay): "each individual, having the internal witness of the conscience, has come to believe that... to those who keep the laws and, should it be necessary to die for them, meet death eagerly, God has granted renewed existence and receipt of a better life at the turn [of the ages]."21

It has been noted in previous research that the recipients of the new life are good souls in all of the passages and that this fits poorly with concurrent Greek thought where liberation from reincarnation is sought. ${ }^{22}$ We shall now take a closer look at A.J. 18.14 in the context of which Mason has repeatedly characterized the new life as the reward mentioned. ${ }^{23}$ This is problematic, since Josephus speaks of a "reward under the earth": the new life would be lived in Hades. ${ }^{24}$ Admittedly, the good souls' new life is a positive consequence of their virtues, but it is the ease of revival, the object in the sentence, which is

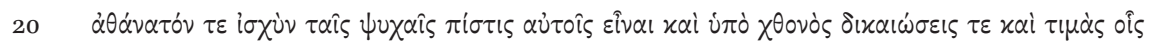

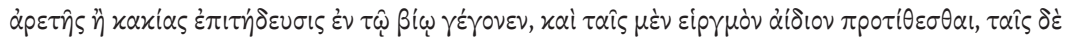
p$\alpha \sigma \tau \dot{\omega} \nu \eta \nu \tau 0 \hat{\alpha} \alpha \nu \alpha \beta 10 \hat{v}$.

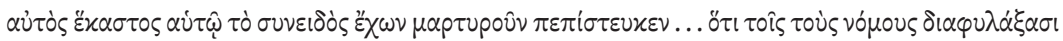

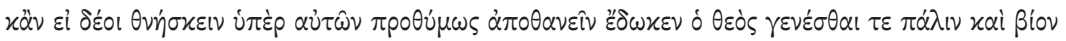

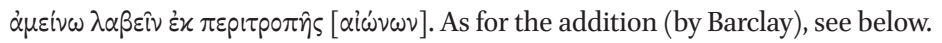

22 E.g., Mason, Pharisees, 166.

23 Ibid., 166; n. 1012 to B.J. 2.163 in War 2.

24 This is the explicit position of Sanders, Judaism, 301. Somewhat inconsistently Mason in Pharisees, 166 n. 194 says that the identification of the reward with the new life "is clear" regardless of whether that life and the eternal imprisonment are elaborations of the punishments and rewards, or additions. He concedes that if they are additions, they may in 
the "reward" meant. ${ }^{25}$ Likewise, the eternal imprisonment is the "punishment under the earth." 26

How should this ease of revival be understood, then? It is difficult to answer this in the context of resurrection; I am not aware of any text that speaks of resurrection being either easy or difficult. Instead, I find the close connections A.J. 18.14 has to Plato's Phaedo enlightening-connections that must have made Josephus's account seem familiar for those who knew the dialogue. In 112a Socrates quotes Homer (Il. 8.14) in his report on the geography of the underworld. He uses the same rare (after the classical period) expression i $\pi \dot{0}$ $\chi$ Đovós ("under the earth") as Josephus. ${ }^{27}$ A little later he, like Josephus, dis-

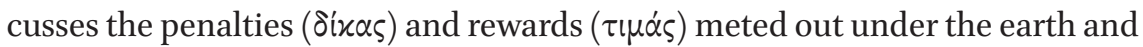
describes how the incurable souls are thrown into Tartarus "whence they never emerge," whereas "those who are found to have excelled in holy living are freed from these regions within the earth and are released as from prisons."28 These

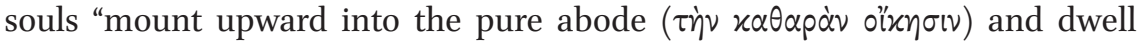

fact be subsequent. But if the new life is subsequent to the period spent under the earth, it cannot the subterranean reward.

25 It is difficult to exclude with full certainty two alternative ways of taking the expression p$\alpha \sigma \tau \dot{\omega} \nu \eta \nu \tau 0 \hat{v} \alpha \nu \alpha \beta$ เôेv. First, it might mean "relief from living again," which would make sense in the context of reincarnation. However, I have not been able to find any certain cases of $\dot{\rho} \alpha \sigma \tau \dot{\omega} \omega \eta$ with a bare genitive in this sense. Philo does in Mos. 2.21 speak of "rest

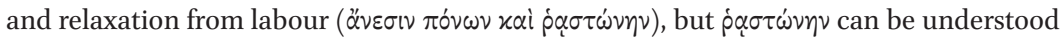

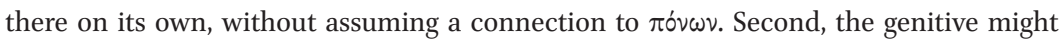
be one of apposition (type urbs Romae) in which case the revival itself would be the relief. See Herbert Weir Smyth, A Greek Grammar for Colleges (New York: American Book, 1920), §1322. However, based on Smyth's example (Plato, Apology 29b) one would expect $\dot{\rho} \alpha \sigma \tau \dot{\omega} \nu \eta \nu \tau \dot{\eta} \nu \tau 0 \hat{\alpha} \alpha \nu \alpha \beta 100 \hat{v}$.

26 In Pharisees, 299 Mason acknowledges that the contrast is between the ease and the imprisonment. As for the word $\alpha \nu \alpha \beta$ 1०v̂v, the present tense implies Josephus does not mean the punctual event of reincarnation but something durative; cf. A.J. 8.327 where the aorist of the same verb describes the sudden revival of the widow's son in 1 Kgs 17:22. The third and final instance of $\alpha \dot{\nu} \alpha \beta$ เó $\omega$ in Josephus in A.J. 11.9 has again the present tense: "And they made the offerings vowed to God and performed the customary sacrifices in accordance with ancient custom, as if their city were being rebuilt ( $\alpha \nu \alpha \kappa \tau i \zeta o \mu \varepsilon \dot{\varepsilon} \eta \varsigma)$ and the ancient form of worship (being) revived ( $\alpha \nu \alpha \beta$ เov́øs)." Both here and in A.J. 18.14 we can make the best sense if we regard Josephus as speaking of the revival process whose end result is a new life. In A.J. 18.14 this process takes place during the period between the lives. Feldman's “an easy passage to a new life" thus quite well reflects the thought in the Greek. Mason notes the phrase in the Iliad (as well as in Aeschylus and Sophocles) but not its reuse by Plato; ibid., 298.

28 See Phaed. 113d-114c. 


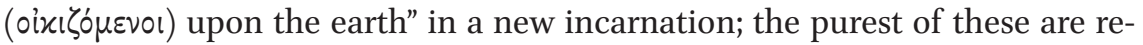
leased from the cycle of reincarnation. There is also a middle class who must first receive pardon from those whom they have wronged in order to "come out and cease from their ills ( $\tau \hat{\omega} v \kappa \alpha x \hat{\omega} v)$ " (114b) and emerge from the underworld. Compared with this last group what the virtuous souls receive is indeed an easy passage to a new life.

That the Phaedo is a relevant background here is made even more plausible by an apposite parallel in Cicero's discussion of Socrates's views of the soul's immortality:

Those who had kept themselves with integrity and chastity, and for whom there was a minimal contagion from their bodies, and who always separated themselves from it and were always imitating the life of the gods in human bodies - for them, there stands open an easy passage to return (reditum facilem) to those from whom they had set out. (Tusc. 1.72) ${ }^{29}$

The context here is precisely the description of the hereafter in the Phaedo. Alexander Long has listed the passages to which Cicero alludes to in $1.71-75{ }^{30}$ For 1.72 his reference seems to be $108 \mathrm{a}-\mathrm{c}$, which should be complemented with ${ }_{113} \mathrm{~d}-114 \mathrm{c} .{ }^{31}$ All the elements of Josephus's description in A.J. 18.14 are present in the Phaedo: rewards and punishments under the earth, easy passage to a new life for some but no passage at all for others. However, as Josephus does not speak of a not-so-easy passage to a new life, nor does he mention the option of final liberation, the match is partial. Regarding the former point, I do, however, think it is warranted to ask whether a contemporary Roman audience-e.g., those who had read their Plato or Vergil ${ }^{32}$ — did not consider it implied that there were also those who were denied precisely the ease of entering a new life. The latter point, final liberation, will be returned to at the end of this article.

29 Tr. Elledge, Life and Death, 111, evidently based on the Loeb translation by King but reworked in many ways. He does not link the passage with A.J. 18.14.

30 A. A. Long, "Cicero's Plato and Aristotle," in From Epicurus to Epictetus: Studies in Hellenistic and Roman Philosophy (Oxford: Clarendon, 2006), 291. The entire list is 80a-d, 108a-c, 84e$85 \mathrm{~d}, 61 \mathrm{c}-62 \mathrm{c}, 67 \mathrm{~d}$.

31 "Holy living ( $\tau \dot{o} \delta \sigma i \omega \varsigma \beta(\hat{\omega} v \alpha \iota)$ " in 113d and 114a is closer to Cicero's "always imitating the life of the gods" than "pass[ing] through life in purity and moderation" in 108c. As for the souls of the dead being brought back, 114b mentions their reincarnation whereas there is no such reference in 108a-c (there is a brief one in 107e).

32 In the underworld of the Aeneid, too, the souls' fates and the degree of ease of the passage to a new incarnation vary. See book 6, lines 735-751. 
Resurrection could well be characterized as a reward, if based on merit. Of the passages outside A.J., in B.J. 2.163 only the souls' goodness is mentioned, but in B.J. 3.374 and C. Ap. 2.218 the new life is more clearly a reward for specified conduct: abiding by, or defending, laws. ${ }^{33}$ In isolation, this may be thought to lend credibility to the idea of resurrection as the underlying referent. However, we also need to consider the other features of the passages (below, sections 4-6). Furthermore, that good souls face re-embodiment is not restricted to resurrection beliefs. We already saw that in the Phaedo one group of the reincarnating souls are said to have "excelled in holy living," and in both the Phaedrus and the Republic the souls that will later be reborn consist of both bad and good ones. ${ }^{34}$ The latter are "made light and raised up into a heavenly place by justice" (Phaedr. 249a) and are called "the just" (Resp. 614c). ${ }^{35}$ Thus what Josephus writes matches very well several, although not all, key elements of the Platonic reincarnation scheme, whereas the chief commonality with resurrection is the reward-like character of the new life itself in two of our four passages.

We then turn to the notion of the body in the accounts in B.J. 2.163 and B.J.

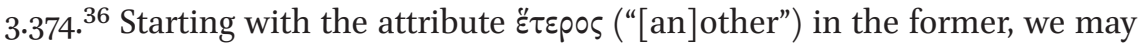
note that Josephus is not speaking of regaining the selfsame body which the soul had during its life. This stands in contrast to 2 Macc 7:10-11 where the resurrected body which the martyr expects to receive back is clearly the one he has

33 In $B . J$. Josephus describes suicide as a breach of both natural law $(3 \cdot 370,374)$ and — without a scriptural warrant-the Jewish legislation (3.377). In C. Ap. the question is of the Mosaic law.

34 Mason's third and fourth "fundamental" characteristics of transmigration are (Pharisees, 166): "good souls affect an early release" from the wheel of reincarnation, and "only the impure and contaminated souls must spend longer periods in the body" (emphasis added). He is right, Josephus's accounts do not reflect the difference between the good and the bad souls in such temporal terms. This follows directly from Josephus's omission of the reincarnation of the impure souls, discussed more below.

35 In the Republic too the good souls go to heaven for the inter-incarnational period (614c). Mason's point (c) in his list of the implied peculiarities in Josephus's descriptions of reincarnation (ibid., 169) — "the soul will wait in heaven until its reincarnation" — is thus no peculiarity at all.

36 Thackeray in a note to his Loeb translation at B.J. 2.163 declares both passages as references to reincarnation, but does not argue for his view. 
at the moment of his death. ${ }^{37}$ On the other hand, that a souls enters "another body" is a natural expression for describing reincarnation. Cf. the following report in Diodorus Siculus: "For the belief of Pythagoras prevails among [the Gauls], that the souls of men are immortal and that after a prescribed number of years ( $\delta \iota^{\prime} \dot{\varepsilon} \tau \hat{\omega} \nu \dot{\omega} \rho\left\llcorner\sigma \varepsilon^{\varepsilon} v \omega \nu\right)$ they commence upon a new life ( $\left.\pi \dot{\alpha} \lambda \iota \nu \beta 10 \hat{v}\right)$ ), the

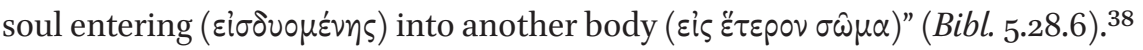

However, it has been suggested that Josephus's referent in B.J. 2.163 is "a new, incorruptible body" along the lines of Paul's discussion of the resurrection body in 1 Cor $15 .{ }^{39}$ It is quite true that the emphasis Paul lays in 1 Cor 15:36-37 on the difference between what is sown and what is quickened certainly makes it clear that the resurrected body is not the same as the one people have during life. However, unlike Paul, Josephus does not say anything of the new body's incorruptibility or immortality in B.J. $2 .^{40}$ But can we take B.J. 2.163 together with the "chaste" body in B.J. 3.374 and assume the adjective árós ("pure," "chaste," "holy") to imply the Pauline type of incorruption of a resurrected body? Not really, if we let the texts speak for themselves. Purity (or holiness) and incorruption do not imply each other, and neither Josephus nor Paul connects these concepts. Paul nowhere refers to the purity or holiness of the resurrected body. ${ }^{41}$ Conversely, words denoting these qualities do not

37 "When it was demanded, he quickly put out his tongue and courageously stretched forth his hands and said nobly, 'I got these from Heaven, and because of his laws I disdain them, and from him I hope to get them back again'” (tr. Joachim Schaper in Albert Pietersma and Benjamin G. Wright, eds., A New English Translation of the Septuagint [New York: Oxford University Press, 2007]). The doubts concerning the identity of the resurrection body with the previous one expressed by Stemberger, Der Leib der Auferstehung (Rome: Biblical Institute Press, 1972), 17, seem unwarranted in light of the text.

38 Elledge, Life and Death, 104, notes the similarity of this passage with B.J. 2.163. Similar expressions were used in Latin literature. E.g., Seneca the Younger describes the Pythagorean reincarnation belief by speaking of the soul "being transferred to another body (in aliud corpus transfunditur)" (Ep. 108.19).

39 This is what Josephus "probably" means according to Segal, Life after Death, 381. Mason mentions "affinities with" 1 Cor 15 in n. 1012 to B.J. 2.163 in War 2.

40 Jonathan Klawans has nevertheless suggested that, as a "parallel contrast" to the eternal punishment of the wicked in B.J. 2.163, "the reward for immortal souls is clearly to pass into some immortal body" (Josephus, 108, emphasis original). This is a very weak argument for such remarkable eisegesis. Plato's example shows (Phaed. 113e, Resp. 615e) that the eternal punishment of the incurable souls and the reincarnation of the rest can coexist. Mason, too, reads "bodily immortality" into Josephus's text (B.J. 3.374) in Pharisees, 160.

41 In Rom 1:4 a "spirit of holiness ('́) linked but without a reference to Jesus's body. 
have such eschatological uses in his letters that would have a bearing on B.J. 3.374. Instead, what emerges is the importance of keeping both the body and the spirit/mind pure during this life (see, e.g., 2 Cor 7:1). ${ }^{42}$

There are also other, Jewish, Christian and Greek texts where the purity or holiness of the human body is something that needs to be maintained (not acquired), which seems to imply that the human body is pure or holy to begin with. ${ }^{43}$ It is in this light I propose we read Josephus's reference to the body's holiness in B.J. $3 \cdot 374 .{ }^{44}$ Several scholars have taken the attribute "holy" to be a new element and not applicable to the bodies mentioned in $\$ 372 .{ }^{45}$ Yet that is implausible. Two examples from Dionysius of Halicarnassus with a similar Greek syntax demonstrate this. ${ }^{46}$ In Rom. Ant. 9.17.5 he writes, "Thereby [Aemilius]

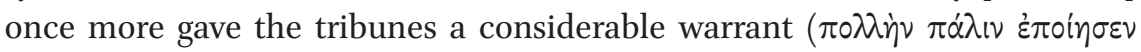

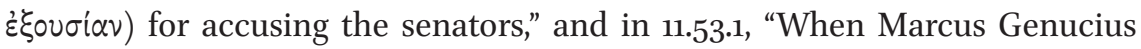
and Gaius Quintius had assumed office, the political quarrels were renewed

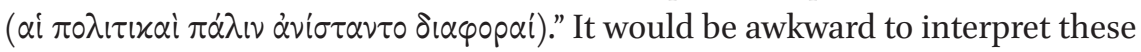
statements to mean that any earlier warrant had not been considerable or that the earlier quarrels had not been of political nature. Thus we cannot take B.J.

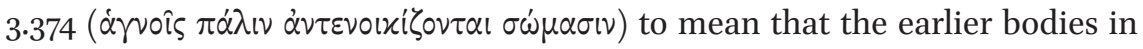
3.372 were not holy. On the contrary, the structure implies just the reverse: they were. Independently of the grammatical considerations, assuming holiness to be a feature of the later bodies only, and thus a hint at resurrection, would lead

42 I have checked the following words and/or their cognates in the Corpus Paulinum (in-

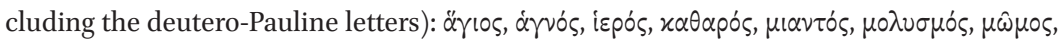

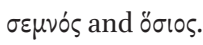

43 This purity is said to be maintainable, e.g., through the abstention from alcohol etc. (Philo, Spec. 1.250), sexual chastity (Dionysius of Halicarnassus, Ant. Rom. 2.68.4; The Acts of Paul and Thecla 12), or moral conduct more generally (cf. 2 Clem. 8:4, 6). All these passages speak of keeping the body/flesh pure, undefiled or holy. Cf. also Phaed. 114b quoted above: reincarnating souls "mount upward into their pure abode," which hardly refers to anything else than the new body they are headed.

44 For reasons that are about to become obvious, I have chosen to use the translation "holy" for árvós. Here I concur with Mason's understanding of the word as "holy, sacred, or consecrated." This is his characterization of the meaning of the word árvós in its four occurrences in Josephus (Pharisees, 167).

45 E.g., ibid., 169: "Josephus makes plain that the new body will be different from the old with respect to its "holiness.'” Similarly Hans C. C. Cavallin, Life After Death:Paul's Argument for the Resurrection of the Dead in I Cor 15, ConBNT 7:1 (Lund: CWK Gleerup, 1974), 143; Wright, Resurrection, 176; Jason von Ehrenkrook, "The Afterlife in Philo and Josephus," in Heaven, Hell, and the Afterlife: Eternity in Judaism, Christianity and Islam, ed. J. Harold Ellens, 3 vols. (Santa Barbara: Praeger, 2013), 1:113.

46 I.e., attribute $+\pi \dot{\alpha} \lambda \iota \nu+$ predicate + noun qualified by the attribute. 
to the difficult question of why Josephus failed to emphasize this supposed singular, eschatological re-embodiment. ${ }^{47}$

But why does Josephus not mention the holiness of bodies in B.J. 3.372 and yet does that a little later? There is a logic to it. We may note that in $\$ 369$ he characterizes suicide as "an act of impiety $(\dot{\alpha} \sigma \dot{\varepsilon} \beta \varepsilon ı \alpha)$ toward God who created

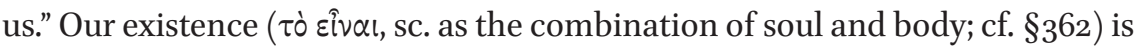
a gift from God who alone should take the decision to end it (\$371). Josephus continues, "All of us, it is true $(\gamma \varepsilon)$, have mortal bodies, composed of perishable matter, but the soul ... is a portion of the Deity housed in our bodies" $(\S 372) .^{48}$ This universal statement is presented as a concession whose point seems to be that although the body is perishable, making it perish is impious, because it houses our divine component. ${ }^{49}$ Thus when Josephus continues, "how can he who casts out from his own body God's deposit, hope to elude Him whom he

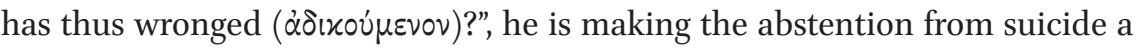
religious duty based on the idea of the divinity of the soul residing in it. ${ }^{50}$ The consecrated nature of the body stems from the indwelling divinity. It would have been out of place to say this in $\$ 372$ where the body's un-soul-like qualities are discussed. ${ }^{51}$ It is thus obvious that the bodies mentioned there are no less holy than those of $\$ 374$. This conclusion means that one of the features most often referred to when Josephus has been claimed to allude to resurrection in especially the passages in $B . J .2$ and 3 cannot be used to support that view.

There is an intriguing parallel to B.J. 3.374 in Wisdom of Solomon that I have not seen discussed in scholarly literature on Josephus. In 8:20 we read, "being

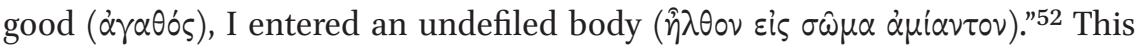

47 Cf. Mason, Pharisees, 167: "entrance into a holy body is a final reward for good souls."

48 This dualism shows that at least ontologically Josephus agrees with point (1) on Mason's list of the features of theories of reincarnation, "the body is antithetical to the soul" (pace ibid., 166).

49 For the concessive force of $\gamma \varepsilon$, see LSJ, II.5. Alternatively, the particle may serve here to highlight the distinction between body and soul expressed by the $\mu \varepsilon \dot{\varepsilon}$ — $\delta \dot{\varepsilon}$ structure; see Smyth, Grammar, §2829. This too fits my interpretation, because Josephus is engaged in explaining the different natures of body and soul now as separate things rather than as a combination.

$5^{\circ}$ As Elledge puts it, "Josephus develops an ethics out of [the anthropological] dualism" of B.J. 3.372-376; Life and Death, 68.

51 Cf. 1 Cor 6:19 (which resonates with the sentiments of God's sovereignty expressed by Josephus): "Or do you not know that your body is a temple of the Holy Spirit within you, which you have from God, and that you are not your own?" (tr. NRSv).

52 Tr. David Winston, The Wisdom of Solomon: A New Translation and Commentary, Ав 43 (New Haven: Yale University Press, 2011). 
seems at first remarkably close to B.J. 3.374 in idea: a pre-existent, good soul enters a pure body. ${ }^{53}$ However, the contexts differ and it seems safest to see the undefiled body in 8:20 as an allusion to a lawful intercourse. ${ }^{54}$

In A.J. 18.14Josephus speaks, literally, of "ease of revival ( $\dot{\rho} \alpha \sigma \tau \dot{c} \nu \eta \nu \tau \tau \hat{v} \alpha \nu \alpha \beta 10 \hat{v})$ " and in C. Ap. 2.218 of souls receiving "a better life (Bíov $\alpha \mu \varepsilon i v \omega)$." Feldman, countering Thackeray's view that Josephus in B.J. 2.163 and 3.374 speaks of reincarnation, states in a note to his Loeb translation at $A . J .18 .14$ that that passage as well as C. Ap. 2.218 and B.J. 3.374 "refer not to metempsychosis, which was not a tenet of the Pharisees, but to the belief in resurrection, which was a central doctrine of the Pharisees." ${ }^{\prime 5}$ This argument is half circular, however: the Pharisees could not be said to believe in reincarnation because it was not a

53 Elledge, Life and Death, 28 n. 116 and "Resurrection and Immortality," 109 entirely misrepresents Winston's view (see esp. Wisdom, 26, 198) as denial of pre-existence in 8:20.

54 Winston's commentary (Wisdom, 199) does not really address the question why the body is called undefiled. To me it seems relevant that the two other instances too of the word ¿ $\mu i \alpha v \tau$ ¿ in Wis are linked to the birth of children: In 3:13 we have, "Blessed is the barren woman who is undefiled, she who has not known intercourse that involved transgression." The closely related verse 4:2 speaks of virtue "having won the victory in the contest for the prizes that are undefiled," the immediate context being, "better is childlessness with virtue" (4:1). Judging by these, the body in 8:20 which the soul enters may in fact be the mother's. Cf. 7:1: "in the womb of a mother I was molded into flesh"; according to Addison G. Wright, Wis 8:17-21 are intentionally linked with 7:1-6. See his "The Structure of the Book of Wisdom," Bib 48 (1967): 164-84, esp. 168. He does not note birth as a connecting theme, although it is pronounced; cf. "when I was born," "beginning of existence" and "entrance into life" in 7:3, 5, 6. If it is the child's own body, the implied possibility of defilement is more difficult to explain, as the children of adulterers are described not in terms of impurity but of dishonor (3:17, 4:19).

55 As mentioned above (n. 36) Thackeray's view is expressed in, e.g., a footnote to B.J. 2.163 in his Loeb translation. In a note to B.J. 3.374 he also cites C. Ap. 2.218 without, however, explicitly referring to reincarnation. Feldman's reference is to Thackeray's Selections from Josephus (London: SPCK, 1919), 159 (this should rather be 124). Feldman repeats his views later but concedes that B.J. 2.163 with its reference to souls passing over to another body "does seem to refer to metempsychosis, however" (Louis H. Feldman, Josephus and Modern Scholarship (1937-1980) [Berlin: de Gruyter, 1984], 431). Alas, he does not comment on the contradiction he now sees between the two accounts of the Pharisaic afterlife beliefs. 
belief of theirs. The other half is that Feldman thinks that the Pharisees did believe in resurrection and that this belief is discussed in A.J. 18.14. He refers to $\alpha \nu \alpha \beta i \omega \sigma \iota \varsigma$ in 2 Macc. 7:9 where it indeed refers to resurrection. However, as has been noted by several scholars, Plato uses the verb $\alpha v \alpha \beta 1 \omega \dot{\sigma} \sigma o \mu \alpha l$ to denote reincarnation in the Phaedo (71e, 72a, d). ${ }^{56}$ However, he also uses $\alpha \dot{\alpha} \alpha \beta$ เó $\omega$ for Er's being restored to life in his funeral pyre in the Republic (614c). None of these is thus the default meaning, and the sense must be judged separately in each case. ${ }^{57}$ Above, the conclusion was reached that Josephus's reference to the ease of revival as the good souls' reward resonates with several of Plato's descriptions of reincarnation but fits ill the idea of resurrection.

The expression "better life" in C. Ap. 2.218 seems to have a Platonic background. ${ }^{58}$ In the Republic the basic alternatives for the soul's next life are the

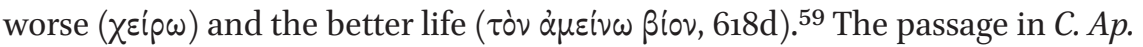
is distinguished from the other new life passages in that now nothing is explicitly said of the wicked. Yet Josephus's statement that being reborn is "granted" to the virtuous souls can be thought to distinguish them from those who do not receive this opportunity. Compared with the myth of Er, this last group would correspond either to the incurable souls who are forever prevented from emerging from the netherworld $(615 \mathrm{e})$ or those who receive the worse life. ${ }^{60}$

There is nothing in the expression "better life" itself that would indisputably prevent it from being a characterization of life after the resurrection of the body. However, I have not found examples of such language actually being used. Furthermore, as this expression appears in tandem with "be[ing] born

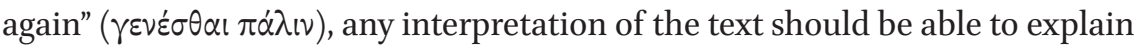

56 Mason, Pharisees, 166; Elledge, Life and Death, 107. Philo uses the noun $\alpha v \alpha \beta i \omega \sigma \iota \varsigma$ for reincarnation in fragment 7.3 Harris; see Yli-Karjanmaa, Reincarnation in Philo, 186-212.

57 Mason (Pharisees, 169) is thus wrong in appealing to the use of $\alpha \nu \alpha \beta i \omega \sigma \iota \varsigma$ in 2 Macc 7:9 as a precedent for Josephus's alleged appropriation of "the language of reincarnation" for resurrection. Cf. also A.J. 8.327 (above, n. 26).

$58 \alpha \mu \varepsilon i v \omega \nu$ ßios as a fixed compound is used between Plato and Josephus only by Philo, but not in explicit relation to the afterlife.

59 Similar options for the following life are presented also in the Phaedrus: "whoever lives

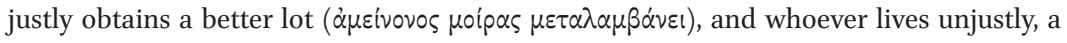
worse ( $\chi$ Épovos)" (248e).

6o One also wonders what the point of comparison for the attribute "better" in C. Ap. 2.218 is. It is hardly the preceding, well-lived life on earth. The option of a worse new life may be implied. The case is similar to the hypothetical group in A.J. 18.14 of those who experience a revival but not the ease of it. 
both phrases. ${ }^{61}$ The translation "renewed existence" for the latter is problematic, since the souls' existence is not threatened and needs no renewal. ${ }^{62}$ The most natural interpretation of the verb is "to be born" (LSJ I.1). However, there

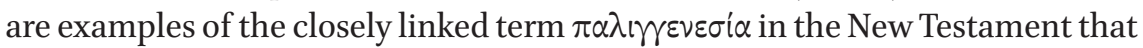
can be thought to be indirectly linked with the resurrection of the body: Matt 19:28 and Tit 3:5. In the former the word, in effect, means the parousia, while the latter, reflecting the idea of an already completed salvation, discusses baptism and is thus a more relevant parallel in speaking of an individual's experience. Hence the language of rebirth does not have to be taken literally to mean a physical birth. ${ }^{63}$ The expressions "to be born again" and "a better life" cannot be said to exclude the option of resurrection. Yet there are no parallels for them in this sense, and as a description of a final, eschatological transformation both would be quite anticlimactic. On the other hand, both have exact antecedents that concern reincarnation. Thus it must be concluded that they would have been a poor choice, had Josephus wanted to include a hint at resurrection in his account.

\section{6}

Recurrence

In this final section before my conclusions I discuss two features found in the passages illustrating Josephus's own beliefs: the way the soul is again housed

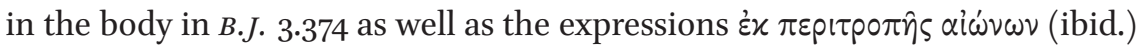

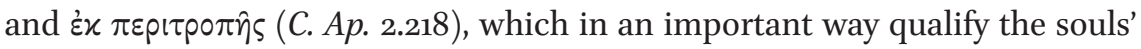
entrance to the new life.

\subsection{The Rehousing of the Soul}

Let us compare the sections B.J. 3.372 and 374 ignoring for now both the attribute "holy" and the results of the syntactical comparison with Dionysius of

61 As Barclay, Apion, n. 367 ad loc. notes, the latter expression occurs in Plato (e.g., Phaed. $7 \mathrm{oc}, 72 \mathrm{a}$-also twice in $71 \mathrm{e}$ and once in $72 \mathrm{~d}$ as well as in Meno $81 \mathrm{~b}$ ), where it means reincarnation.

62 Both Barclay (ibid.) and Wright (Resurrection, 176) use the expression quoted. The latter's translation has also other problems, for the sequel goes, "to receive a new (sic) life out of the renewal."

63 It is metaphorical also in its only occurrence in Josephus, A.J. 11.66. There are examples of other usage also in Philo who, pace Mason, Pharisees, 163 n. 176, nevertheless uses $\pi \alpha \lambda ı \gamma \varepsilon v \varepsilon \sigma i \alpha$ to mean reincarnation in Cher. 114; see Yli-Karjanmaa, Reincarnation in Philo, 150-67. 
Halicarnassus discussed above. Thackeray's translations conceal the high degree of similarity in the Greek:

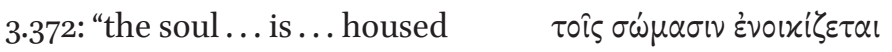

$$
\begin{aligned}
& \text { in our bodies" }
\end{aligned}
$$

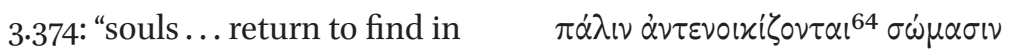

$$
\begin{aligned}
& \text { bodies a new habitation" }
\end{aligned}
$$

The similarity of these two sentences implies a highly significant fact ignored in previous research: We know that incarnation through ordinary birth must be meant in the first one, and thus we should be able to add to it the force of the combination $\pi \dot{\alpha} \lambda \imath v+\dot{\alpha} v \tau i$ to arrive at the meaning of the second. But what exactly is that force?

The adverb $\pi \dot{\alpha} \lambda \iota v$ has four main meanings referring to the direction back(wards), to contrariety, to repetition or to something happening in turn (LSJ). The preposition $\alpha \dot{v} \tau$ í in compositions chiefly refers to opposition of various kinds. ${ }^{65}$ In order to clarify as far as possible the meaning of their combination in B.J. 3.374, I have looked at similar expressions in Thucydides, Philo and Josephus himself. The results seem clear enough: while the referent of $\pi \dot{\alpha} \lambda \imath v$ is some earlier action, event or state, $\alpha \nu \tau i$ refers to a later action, event or state which is one of reversal. Let us see examples of this pattern: ${ }^{66}$

Thucydides, Hist. 2.13.5: "but having made use of [a treasure] for their safety', he said, 'they were to make restitution of the like quantity again

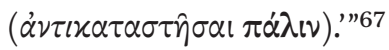

Hist. 2.65.9: "When he saw them unreasonably afraid, he would restore

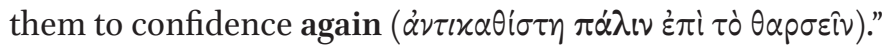

Philo, Leg. 2.92: "There shall be once more a rod instead of a serpent

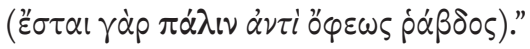

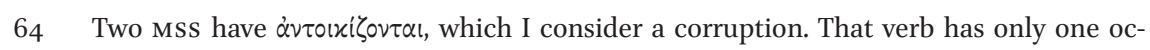
currence in the whole TLG (Procopius, Comm. in Is. p. 2677 l. 42) and no entry in the LSJ. While $\alpha \nu \tau \varepsilon v o w i \zeta \omega$ is not much more common with its three appearances, as the counterpart of $\dot{\varepsilon} v o u x i \zeta \omega$ it is more probable.

65 LSJ: 1. over against, opposite; 2. against, in opposition to; 3 . one against another, mutually; 4. in return; 5 . instead of; 6. equal to, like; 7. corresponding, counter.

66 I have marked in bold $\pi \dot{\alpha} \lambda \mathrm{l} v$ and the corresponding part in the translation, with italics, $\dot{\alpha} \nu \tau i$ and its translation.

$67 \quad$ I have used the translation by Thomas Hobbes here because it does not conflate $\pi \dot{\alpha} \lambda \mathrm{l} v$ and $\alpha \nu \tau i$ like the more modern translations do; The English Works of Thomas Hobbes of Malmesbury: Thucydides (London: Bohn, 1843). 
Somn. 2.12: "For at times the appetite flows strongly to wealth and reputation and completely masters the interests of body and soul, and then again is met and driven back ( $\varepsilon \hat{\imath} \tau \alpha \dot{\alpha} \nu \tau \iota \beta \iota \alpha \sigma \theta \varepsilon i \sigma \alpha \pi \dot{\alpha} \lambda \iota v)$ "

B.J. 2.190: " ... and empty the basin of its sand, whereupon it is refilled again ( $\pi \dot{\alpha} \lambda \iota \nu \dot{\alpha} \tau \tau \iota \pi \lambda \eta \rho \circ \hat{\tau} \tau \alpha l)$ by the action of the winds."

A.J. 12.377: "Every siege-engine ( $\mu \varepsilon \chi \alpha \dot{\alpha} \eta \mu \alpha)$ which the king set up against them, they, in turn, countered with another engine ( $\pi \dot{\alpha} \lambda เ \nu \dot{\alpha} \nu \tau \varepsilon \mu \eta \chi \alpha \nu \omega \hat{\omega} \nu \tau 0)$.

In these examples, the adverb $\pi \dot{\alpha} \lambda \imath \nu$ and the preposition $\dot{\alpha} \nu \tau i$ both relate to an original state of affairs, but they have a different point of reference. The former refers to the restoration of the original state, ${ }^{68}$ whereas the latter refers to the way that state is reachieved: through the cancellation of an intermediary state. ${ }^{69}$ This grammatical structure itself in no way limits the number of the alternations.

How does B.J. 3.372-374 fit this pattern? Josephus says that the souls of those who do not commit suicide "are allotted the most holy place in heaven, whence

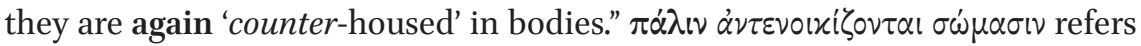
to a reversal of the allotment of the place in heaven with the result that the state of being housed in a body again prevails.

When we combine this result with the earlier conclusions that holiness, the innate quality of every body containing the divine soul, is part of the circumstances that recur, the signs of continuity and similarity between the incarnations are marked indeed. Would Josephus have used such language if he had wanted to convey the idea that the latter incarnation was the final, "singular, climactic movement into a new body," as Mason describes it?" ${ }^{70}$ My answer is no, because — regardless of the audience — the Greek is clear enough: ordinary birth in a holy body is repeated.

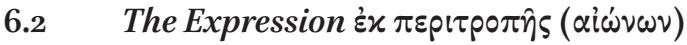

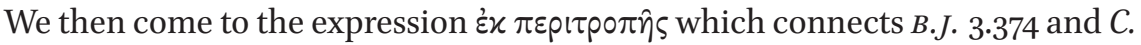
Ap. 2.218. In the former, the re-housing of the soul takes place "in the revolution

68 I.e., the treasure being intact, the state of confidence, the rod as it originally was, the appetite being held back, the basin being full, and an even number of siege-engines, respectively.

69 I.e., the treasure being partly used, fear, the rod being a serpent, the appetite flowing strongly, the emptiness of the basin and an odd number of siege-engines, respectively.

70 Mason, Pharisees, 167 . He also says, "Josephus is talking about a holy or sacred body that will bring a better life"; ibid., 167, 169 point (a). However, Josephus does not present the new body and the better life in a causal relationship. 
of the ages ( $\dot{\varepsilon} \varkappa \pi \varepsilon p \iota \tau \rho \circ \pi \hat{\eta} \varsigma \alpha i \dot{\omega} \omega \omega \nu)$." In the latter, the law-protecting souls are allowed to be reborn and to receive a better life "at the turn [of the ages] ( $\dot{\varepsilon} \chi$

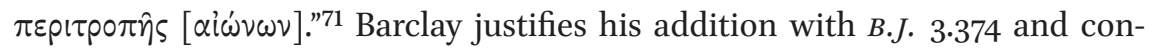
cludes, "Josephus probably shared the Pharisaic belief in a single decisive change, the dawn of "the age to come." 72 The key question is whether Josephus means a linear process or a cyclical one. ${ }^{73}$ Any interpretation must account for the specifics of the Greek as far as possible.

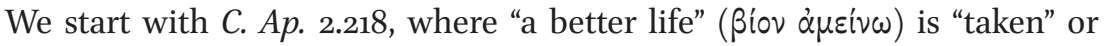
"received" ( $\lambda \alpha \beta \varepsilon i \hat{\nu})$, and this receipt is specified as happening $\dot{\varepsilon} x$ $\pi \varepsilon p \iota \tau p o \pi \hat{\eta} \varsigma$. Barclay and Whiston have translated this expression as if it were simply the same as $\dot{\varepsilon} v \pi \varepsilon \rho \imath \tau \rho \sigma \pi \hat{\eta}$, as has Thackeray in B.J. 3.374. LSJ does record the meaning "at, in" for $\dot{x} x$ in temporal expressions (II.3), but in all the examples the related noun denotes a time $(\nu \dot{\xi} \xi, \dot{\eta} \mu \dot{\varepsilon} \rho \alpha)$. Hence such a translation of these Josephan passages should be argued for. In C. Ap. 2.218 the preposition $\dot{\varepsilon} \chi$ could in fact be taken in its concrete sense "from," if the passage was seen against the background of Plato's Republic as Barclay suggests. ${ }^{74}$ However, this

71 Tr. Barclay. We may note the Old Latin translations of these phrases here. In B.J. 3.374 we have "atqve inde rursum, volventibus seculis, casta corpora jubentur incolere," in C. Ap. 2.218, "dedit enim deus rursus fieri, ut vita melior possit ex mutatione conferri."

72 Barclay, Apion, n. 368 ad loc. I am reluctant to harmonize passages the way Barclay does without compelling reasons.

73 Elledge sees here a reference to the cosmic conflagration, but he does not make it clear why he assumes that an intrusion of Stoic cosmology in the middle of a very Platonic description of the soul's journey is the most likely context for Josephus's language (Life and Death, 56, 68, 113). There is no shortage of cyclicality in Plato's descriptions of reincarnation. To take just two examples, the souls about to be reborn are declared in the Republic: "this is the beginning of another round of mortal kind that ends in death ( $\alpha$ px $\dot{\eta}$

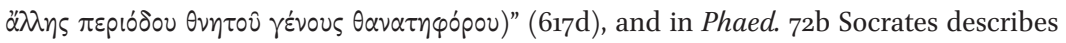
the process of reincarnation as a "cycle." Point (b) in Mason's list of what he implies to be peculiarities in Josephus's accounts (Pharisees, 169) states, "only one such body seems to be envisioned," not a cycle. This view rests on his questionable interpretation of the new body as holy and singular as well as his understanding of the $\pi \varepsilon p \iota \tau \rho \circ \pi \dot{\eta}$ expressions as referring to "one change in a series or succession" (p. 168) = his point $(\mathrm{d})$.

74 Barclay (Apion, n. 368 ad loc.) refers to both Plato's Republic and Cicero's Republic as precedents to $C$. Ap. in that they too finish a summary of the laws with an eschatological expectation. In Plato, the "mechanism" operated by Necessity and the Fates in the distribution of new lives for souls is emphatically one of revolving and turning (Resp.

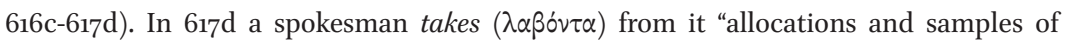
lives ( $\beta^{\prime}(\omega v)$ " - better and worse ones (618e). In 62ob Atalanta's soul "takes" ( $\left.\lambda \alpha \beta \varepsilon i ̂ v\right)$ an athlete's life. 
interpretation-concretely receiving lives from a revolving system-does not fit $B . J \cdot 3 \cdot 374 .^{75}$

The expression $\varepsilon \dot{\chi} \pi \varepsilon \rho \tau \rho \circ \pi \eta \dot{\zeta}$ has a recognized adverbial meaning, expressed by LSJ as "by turns," "one after another." 76 Again, this could work for C. Ap. 2.218: virtuous souls could receive better lives one after another. But in B.J. 3.374 the expression should is qualified by a genitival attribute. How should that attribute be understood? We may first note that the description in LSJ is somewhat inadequate in the light of the use of the phrase. There are only three or four occurrences before Josephus by two authors, Dionysius of Halicarnassus and Philo of Alexandria, and while Dionysius does use it in the sense given by LSJ, in Philo it has another one, not reflected in the LSJ entry. ${ }^{77}$ His both instances are related to the metaphor of a recurring disease. The first example comes from Mos.:

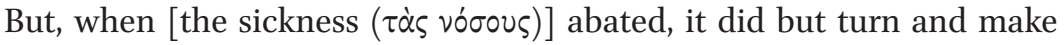
a fresh attack ( $\alpha \hat{\imath} \theta i \varsigma \dot{\varepsilon} \varkappa \pi \varepsilon p \iota \tau \rho \circ \pi \hat{\eta} \varsigma \dot{\varepsilon} \pi \varepsilon \tau i \theta \varepsilon v \tau o)$ and gather from the breathing-space some new misery more powerful than its predecessors. (Mos. 1.42)

In Legat. Philo writes,

Apelles [was] tortured by the rack and the wheel periodically $7^{78}$

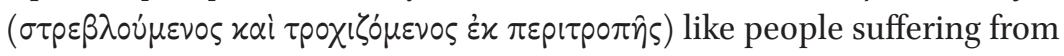

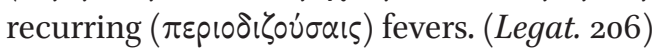

Josephus himself uses the expression a third time:

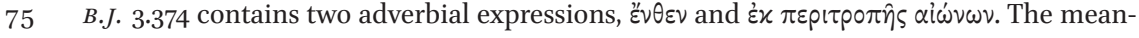
ing "from" for $\varepsilon \varkappa$ would make the second one a locative expression and the first, a temporal one, whereas it seems much more natural to take them the other way around.

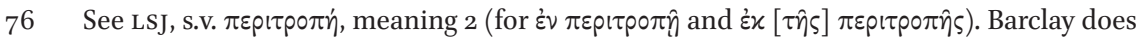
not refer to this; Mason, based on examples, notes the meanings "in succession" and "in turn"; Pharisees, 168.

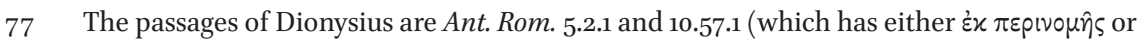
$\varepsilon \dot{\varepsilon} \pi \varepsilon \rho(\tau p \circ \pi \eta \hat{\varsigma})$. These are quite similar to B.J. 4.207: "every man was bound to fall in for

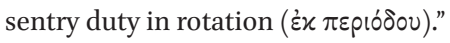

78 The translator (Colson) actually has "in turns" in the main text but notes, "Or 'periodically' (rack and wheel being regarded as a single process), which suits the figure of recurrent

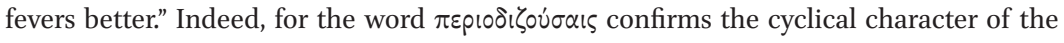
event described. LSJ gives as an example Strabo, Geogr. 7.2.1 where the flood and ebb of the sea are characterized as $\pi \varepsilon p 10 \delta$ ı 
This calamity befell the city of Jerusalem... on the day of the Fast, as if it were a recurrence of the misfortune which had come upon the Jews in the time of Pompey (

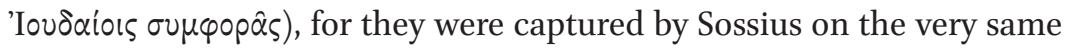
day, twenty-seven years later. (A.J. 14.487)

In these three examples $\dot{\varepsilon} x \pi \varepsilon p i \tau p o \pi \hat{\jmath} \varsigma$ refers to recurrence. ${ }^{79}$ This meaning too fits C. Ap. 2.218: "those who keep the laws... God has allowed to be reborn and to receive a better life again." Similarity with the earlier life is, once more, implied. This favors reincarnation as the referent; I can detect no peculiarities to imply any hint at resurrection.

What about B.J. 3.374? The last example in $A . J$. is extremely interesting because there too $\varepsilon x \pi \varepsilon p \iota \tau \rho \pi \eta \dot{n} \zeta$ is followed by a noun in the genitive. In that case the noun tells us what it is that recurs: "befell ... as if it were a recurrence

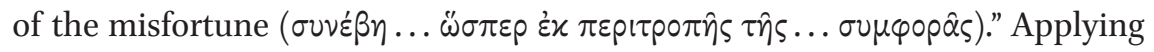
this logic to B.J. 3.374 leads to the idea that embodiment happens "when ages recur."

What does that mean? I think the most natural solution follows from the sense "completion of an orbit and return to the same point" of the preposition $\pi \varepsilon p$ í in compositions (LSJ F.II). A reincarnation-related time cycle can be said to have a "beginning" (Resp. 617d): as it revolves, the new incarnations always take place once the wheel has gone a full circle. ${ }^{80}$ Such cosmic cycles, related both to the durations of the inter-incarnational periods and incarnations are a

79 Mason appeals to the uniqueness of the recurrence of the event in A.J. 14.487 to support his view that the re-embodiment described in B.J. 3.374 is also a one-time event (Pharisees, 168). However, in Antiquities the uniqueness involved is entirely contingent. He also discusses Philo but, while ignoring the passage in Embassy, characterizes the one in On the Life of Moses as "referring to a sudden change in one's physical condition." This blurs the oscillating nature of the troubles Philo has been describing (see especially Mos. 1.31, 41). Yet A.J. 14.487 shows that the expression can refer to a one-time recurrence.

8o See the quote from the Republic in n. 73. This is why Mason's statement that $\dot{\varepsilon} \varkappa \pi \varepsilon p \iota \tau \rho \circ \hat{\eta} \varsigma$ and $\dot{\varepsilon} v \pi \varepsilon \rho \tau \rho \rho \pi \hat{\eta}$ "have to do, then, not with perpetual motion but one change in a series or succession" (ibid., 168) is inaccurate. I agree with him that "when one age comes to an end the next begins," but this in no way precludes cyclicality. Cf. Cornfield's rendering in B.J. 3.374, "when the wheel of time has turned full circle" in Gaalya Cornfeld, Benjamin Mazar, and Paul L. Maier, Josephus: The Jewish War: Newly Translated with Extensive Commentary and Archeological Background Illustrations (Grand Rapids: Zondervan, 1982) (non vidi) which Mason (Pharisees, 167 n. 199) prefers to Thackeray's and Whiston's "in the revolution of the ages." Cf. also Wright's "when the ages come round again" (Resurrection, 176). 
standard feature of Platonic and Platonist doctrine. ${ }^{81}$ Note, for example, how Vergil describes the time for reincarnation: "when time's cycle is complete (perfecto temporis orbe)" (Aen., 6.745). Thus a strong case must be made that Josephus's audience would have understood his temporal expression as cyclical and thus referring to reincarnation. As a translation this interpretation would in B.J. 3.374 be represented by "as the aeons complete a full circle [the souls] are again housed in holy bodies." Thus the expression $\varepsilon x \pi \varepsilon p \iota \tau p \circ \pi \hat{\eta} \varsigma$ is best understood as referring to recurrence (without $\alpha i \omega \omega \omega \omega \nu$ ) or the completion of a full circle (with it) with a continuous cycle implied.

\section{Conclusions and Questions for Further Research}

This study has found that Josephus's "new life" passages should be understood as characteristic but partial descriptions of reincarnation. This twofold conclusion derives, on the one hand, from Josephus's terminology, the ordinary manner of birth into a ordinary body implied and the cyclicality of the phenomenon described, and, on the other, from the omission of the category of reincarnating wicked souls and of the final salvation out of the perishable body. ${ }^{82}$ The other features that have in earlier research been interpreted as anomalous for reincarnation or hints at resurrection were found to fit well the tenet of reincarnation. ${ }^{83}$

The texts presenting Josephus's own views are more complex in terms of both contents and language than those dealing with the Pharisees, and of the translations presented above in Table I, it is these that should in my view be amended. My proposals for translating the key expressions are as follows:

B.J. 3.374: "as the aeons complete a full circle, they are again housed in holy bodies," and

81 See the discussion in Yli-Karjanmaa, Reincarnation in Philo, 117-19, 136-38.

82 The Josephan scheme might, albeit on a much more general level than is the case with reincarnation —and only by overlooking its specifically reincarnational features—also be said to be a partial reproduction of the belief in resurrection (I thank the anonymous reviewer of this article for suggesting the consideration of this point). E.g., in 2 Macc 7:9-14 there is resurrection "into eternal life" for the martyrs but none for the tyrant; thus both of Josephus's omissions are features that link his accounts with resurrection.

83 Most of these are encapsulated in Mason's points (a) to (d) in Pharisees, 169, to which we may add the verb $\alpha^{2} \nu \alpha \beta \iota^{\prime} \omega$ in A.J. 18.14. 
C. Ap. 2.218: "those who keep the laws... God has allowed to be reborn and to receive a better life again."

Yet Josephus's two omissions make it problematic to simply declare that he claims that he and the Pharisees believed in reincarnation, let alone that this simply was the case in reality. Of them, the absence of the reincarnating wicked is the more significant one, whereas the final liberation is almost lost to view also in, e.g., Plato's Republic, where only a brief and indirect reference to being "saved" is found (621 b-c). I end this article with some thoughts on a way towards solving the question of how to understand and explain the incompleteness of the Josephan reincarnation scheme.

Mason has suggested that the difference between the Essene and Pharisaic beliefs concerning the post-mortem fate of the virtuous souls

may not be as great as it seems, however, since Josephus' own character speaks about the souls of the good going first to a heavenly place and then to "holy new bodies" - in the revolution, or succession, of ages ( $\dot{\varepsilon} x$ $\pi \varepsilon p \iota \tau p o \pi \hat{\eta} \varsigma \alpha i \dot{\omega} v \omega \nu$ ): War 3.375 (sic); Apion 2.218. He thus envisages an intervening period of the soul's existence before its re-incarnation. ${ }^{84}$

On this interpretation the Essene belief in the post-mortem ascent of the soul (B.J. 2.155) is to be identified with the allotment of "the most holy place in heaven" (3.374), followed by the transfer to "holy" (ibid.), i.e., the "other" (2.163) bodies. However, while the first part seems plausible, Josephus does not even hint at an Essene belief that the soul's reward would not be final. This harmonization has also another, bigger problem: bodily immortality would contradict Josephus's unequivocal statements in B.J. 2.154 and 3.372 that the human body is perishable. Only by postulating some kind of immaterial bodies or imperishable matter, wholly extraneous to anything Josephus wrote, could we accept the view of the body as the final destination of souls for Josephus or his Essenes.

Nevertheless, some other combination of beliefs could be both coherent as a scheme and justified in light of what Josephus says. In addition to the body's mortality, worth attention are the statements that souls "emanate from the most refined ether" (Essenes, B.J. 2.154) and that the soul is "a portion ( $\mu$ oi $\rho$ ) of God" (Josephus, B.J. 3.372). ${ }^{85}$ In the Essene view of salvation the joyous ascent

\footnotetext{
84 Mason, War 2, note 1012 to B.J. 2.163.

85 The former idea appears, e.g., in the pseudo-Platonic dialogue Axiochus (366a), the latter is mentioned by Cicero as a Pythagorean tenet (De natura deorum 1.27). Philo brings them
} 
( $\mu \varepsilon \tau \varepsilon \dot{\omega} \rho \circ \cup \varsigma$ $\varphi \varepsilon \varepsilon \rho \varepsilon \sigma \alpha \iota)$ is preceded by a long imprisonment, slavery and bondage in the body (B.J. 2.154-155). ${ }^{86} \mathrm{It}$ is in my view a noteworthy alternative to be explored whether that confinement is meant to imply a period of reincarnation. For example, Plato uses all three images and the same vocabulary for the soul's stay in the body in the Phaedo: slavery at $66 \mathrm{~d}$, bondage at $67 \mathrm{~d}$ and imprisonment at 82e.

The various afterlife beliefs in Josephus are curiously compatible. Not only does the harmonization of the Essene, Josephan and Pharisaic beliefs seem possible if we assume that the different accounts, for some reason to be investigated, reveal different parts of a bigger picture, but also the speeches by Titus (B.J. 6.46-49) and Eleazar (B.J. 7.343-349) provide several further commonalities with especially the Essene and Josephus's own beliefs. Space does not permit discussing them here. More research is needed to enable us to understand the totality of the Jewish afterlife beliefs Josephus brings forward and their mutual relationships.

together in Leg. 3.161: "the soul is ethereal, a divine particle $(\dot{\alpha} \pi \delta ́ \sigma \pi \alpha \sigma \mu \alpha \theta \varepsilon \hat{\varepsilon} 0 \nu)$... a portion

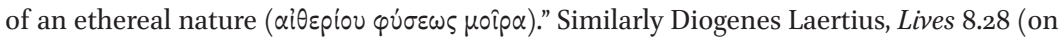
Pythagoras).

86 Seemingly quite incongruously Josephus then depicts the souls' abode as a comfortable place "beyond Oceanus," described in vivid physical terms and compared to the Islands of the Blessed of the Greeks (B.J. 2.156). Like the accounts of the underworld in the Phaedo discussed above, this is an overtly mythical description; the Essene view of the impermanence of matter cannot literally accommodate any such physical environment as the final abode of incorporeal souls. Indeed, Josephus immediately clarifies what the essence of this "mythologizing" (2.156) is: "For the good become even better in the hope of a reward also after death" (2.157). Josephus's explanation resonates with the modern definition of myth as a narrative conveying beliefs; see Bowker, $O C D W R$, s.v. "Myth." Narratives conveying similar beliefs may also contradict each other; thus whether the souls come to their new lives from the underworld (A.J. 18.14; see the discussion on the Phaedo above and cf. also Tim. 44c) or heaven (B.J. 3.374; Resp. 614c-e, 619d-e; Phaedr. 249a-b) is secondary to the belief (reincarnation) conveyed. Cf. also Pindar, Ol. 2.55-72, where we have an example of apparent reincarnation followed by going to the Islands of the Blessed. 